\title{
СУЧАСНІ ЗАСОБИ ФІЗИЧНОЇ ТЕРАПІЇ ПРИ ПЕРЕЛОМІ ГОМІЛКИ
}

\author{
І. Р. Мисула, Ю. А. Андрусевич \\ Тернопільський національний медичний університет \\ імені І. Я. Горбачевського МОЗ України
}

Стаття присвячена вивченню та аналізу науково-методичної літератури щодо засобів і сучасних методів фізичної реабілітації хворих із переломами кісток гомілки. Встановлено, що основними методами, які застосовують у процесі реабілітації, є лікувальна фізична культура, масаж, фізіотерапевтичні методи. Сучасними методами у процесі реабілітації є кінезитейпування, кріотерапія, механотерапія та новітні апарати, що працюють на основі віртуальних програм.

\section{MODERN MEANS OF PHYSICAL THERAPY FOR THE TIBIA FRACTURE}

\author{
I. R. Mysula, Yu. A. Andrusevich
}

\section{Horbachevsky Ternopil National Medical University}

The article is devoted to the study and analysis of the scientific literature on the means and modern methods of physical rehabilitation of patients with fractures of the tibia. It is established that the main methods used in the rehabilitation process are therapeutic exercises, massage, physiotherapy methods. Modern methods in the process of rehabilitation are kinesiotaping, cryotherapy, mechanotherapy and the latest devices that work on the basis of virtual programs.

Вступ. Переломи кісточок гомілки за кількісними показниками посідають друге місце після переломів променевої кістки в «класичному місці» і складають 20-28 \% від усіх переломів кісток кістяка людини, 3560 \% усіх внутрішньосуглобових переломів нижньої кінцівки та 38-80 \% усіх переломів кісток гомілки [2].

Пошук засобів і методів фізичної реабілітації пацієнтів після лікування переломів кісток гомілки $\epsilon$ актуальною проблемою сучасної травматологічної науки та фізичної реабілітації.

Основна частина. Фізична реабілітація відіграє важливу роль у лікуванні перелому кісток в нижній третині гомілки для повного і якнайшвидшого функціонального відновлення кінцівки після травми та попередження різноманітних ускладнень з боку опорно-рухового апарату (ОРА), серцево-судинної та дихальної систем. Застосування сучасних методів фізичної реабілітації потребує обов'язкового врахування стану хворого, особливостей перебігу травматичного процесу і стадії регенерації.

До основних завдань фізичної реабілітації при оперативному лікуванні перелому нижньої третини

(ㄱ. Р. Мисула, Ю. А. Андрусевич, 2021 гомілки належать: знеболювальний ефект; прискорення загоєння рани і утворення кісткової мозолі; прискорення відновлення функції кінцівки в цілому; покращення психоемоційного стану [1] .

3 метою реалізації поставленого завдання, важливо забезпечити цілеспрямоване формування плану реабілітаційної програми у комплексному лікуванні пацієнтів із переломом гомілки.

Згідно з дослідженням автора [4], найефективнішим методом фізичної реабілітації є механотерапія, що характеризується виконанням комплексу лікувальних, профілактичних та відновлювальних вправ за допомогою спеціальних засобів на покращення рухливості суглобів, окремих м'язів та їх груп для підвищення функціональної адаптації хворого до поступових навантажень.

Прикладом впровадження здобутків науковотехнічного прогресу у фізичну реабілітацію $є$ застосування пристроїв з інтегрованою функціональною електростимуляцією. Окремо нервово-м'язову електростимуляцію давно використовують в реабілітаційній практиці, але новітні технічні досягнення дозволили впровадити у конструкції роботизованих

18 ISSN 2411-1597. МЕДСЕСТРИНСТВО. 2021. № 2 
та механотерапевтичних апаратів функціональну електростимуляцію.

Новітні апарати оснащують обладнанням віртуальної реальності (VR-функції). Технічні засоби передають пацієнтові сенсорну інформацію з функцією зворотного зв'язку та укріплюють м'язи гомілки, які при переломі гомілкової кістки гіпотрофовані. Такі роботи створюють тренувальне навантаження 3 найбільш відповідними параметрами для індивідуальних занять.

У ранній та пізній післяопераційні періоди відновлення хворих після оперативного лікування нижньої третини гомілки застосовують апарат СРМ для пасивного безперервного відновлення рухливості колінного та гомілковостопного суглобів [4].

Попадюха Ю. А. вважає, що «СРМ-терапія має ряд переваг над пасивною розробкою спеціалістом 3 фізичної терапії: тренажери можна використовувати хворим після оперативного перелому нижньої третини гомілки в будь-який час як у ранньому, так і у пізньому післяопераційному періоді; СРМ-терапія дає впевненість в отриманні безболісних і добре відрегульованих рухових вправ, яка базується на можливості розслабити хвору кінцівку під час заняття, виставити діапазон рухів та швидкість виконання вправ; систематичні заняття на тренажері, до яких хворі швидко звикають, зменшують страхи, які досить часто присутні у хворих з контрактурою, допомагають їм розслабитись і збільшують бажання займатися» [4].

Великою популярністю серед травматологів користується кріотерапія - розділ фізіотерапії, що характеризується використанням холодних температур для лікування та фізичної реабілітації. Носії холодних впливів можуть бути у твердому, рідкому або газоподібному стані. За температурними показниками їх поділяють на дві групи: помірно низьких температур (від +20 до $-30^{\circ} \mathrm{C}$ ) та низьких температур (від -30 до -180 ㄷ). Залежно від площі тіла кріотерапія буває локальною та загальною. Після оперативного втручання перелому гомілки рекомендують використання локальної кріотерапії [5].

Масаж відіграє найважливішу роль у фізичній реабілітації травмованої кінцівки, а також сприяє прискоренню кровообігу, розширенню шкірних судин, підвищенню кровопостачання тканин. Після зняття гіпсу хворим найчастіше призначають лікувальне розтирання, яке спрямоване не лише на лікування застійних явищ, атрофії і контрактур, а й на підви- щення загального тонусу м'язів нижньої кінцівки, повернення еластичності, а також на максимально швидке відновлення рухової активності пацієнта [ 3]. Крім того, застосування такого масажного прийому, як розтирання, дозволяє впоратися з набряками, які виникають вище і нижче місця перелому. Розтирання м'язів проводиться в коловому, поздовжньому та поперечному напрямках зі значним тиском для того, щоб промасажувати не лише шкірний покрив, але й проникнути у глибоко лежачі тканини. Масаж виконують кінчиками пальців, основою долоні та великими пальцями з додатковим використанням різноманітних спеціальних кремів, які містять речовини, що сприяють відновленню тканин (Колаген Плюс, Хондроксид, Гепатромбін тощо). Однак існують протипоказання до застосування масажу, які варто враховувати під час призначення курсу масажу, зон впливу й інтенсивності його виконання. Серед них виділяють захворювання шкіри, порушення кровообігу, а також серцево-судинні патології.

Кінезитейпування - це новий метод нанесення спеціальної стрічки (кінезитейпа) на різні ділянки тіла людини з метою зняття болю, відновлення рухливості суглобів і навіть корекції фігури. Метод активно використовують сучасні фахівці з реабілітації, спортивної та відновної медицини і він дозволяє досягти ефекту максимально швидко і значно його продовжити, аж до повного відновлення знижених функцій організму [6]. Тейп активізує власні захисні механізми тканин, не обмежуючи свободи рухів через посилення лімфовідтоку, збільшення міжтканинного проміжку, підтримки правильної амплітуди рухів у суглобах.

Вкрита тейпом ділянка тіла людини натягується, що створює проміжок між шкірою та м'язом, забезпечуючи тим самим відтік лімфатичної рідини. У результаті - рівень болю знижується на 70-80 \%, запальний процес вгамовується, забезпечується нормальний відтік лімфи та розслаблення м'язів, полегшується рух кінцівки чи суглоба, зменшується набряк та гематоми, а суглоб м'яко стабілізується.

Висновки. 1. Застосування сучасних засобів фізичної реабілітації у пацієнтів із переломом гомілки $\epsilon$ ефективним.

2. Висока ефективність сучасних засобів фізичної реабілітації реалізується при їх поєднаному застосуванні з традиційними методами - лікувальною фізкультурою, масажем. 


\section{СПИСОК ЛІТЕРАТУРИ}

1. Іпатов А. В. Проблеми інвалідності та реабілітації інвалідів ортопедотравматологічного профілю / А. В. Іпатов // Ортопедія, травматологія та протезування. - 2002. № 4. - С. 12-17.

2. Уніфіковані клінічні протоколи первинної, вторинної та третинної медичної допомоги / М. П. Комаров, Г.В.Гайко, О.М.Ліщишина та ін., 2018.

3. Никаноров А. Применение нетрадиционных методов восстановления в комплексной реабилитации больных с переломами костей нижних конечностей / А. Никаноров // Теория и методика физического воспитания. - 2005. - № 2/3. - С. 56-59.
4. Попадюха Ю. А. Сучасні комп'ютеризовані комплекси та системи у технологіях фізичної реабілітації : навч. посіб. / Ю. А. Попадюха. - К. : Центр учбової літератури, 2017. - 300 c.

5. Лукомский И. В. Физиотерапия. ЛФК. Массаж / И. В. Лукомский, Э. Э. Стэх, В. С. Улащик ; под ред. В. С. Улащика. - 2-е изд. - Минск : Высшая школа, 1999. - 217 с.

6. Глиняна О. О. Основи кінезіотейпування: навч. посіб. / О. О. Глиняна, Ю. В. Копочинська. - К. : КПІ ім. Ігоря Сікорського, 2019. - 142 с.

Отримано 05.04.21 